\title{
Implementation of Legal Presumption Principle for Notary Deed Makes Partij According to Law No. 2 of 2014 on the Amendment of Act No. 30 of 2004 Concerning Notary Position
}

\begin{abstract}
Najmi Amudy ${ }^{1}$, Sujatmika ${ }^{2}$ and Achmad Sulchan ${ }^{3}$
Abstract. The purpose of this study was to: 1) To identify and analyze the implementation of the principle of presumption valid for notaries who make Partij deed according to Law No. 2 of 2014 concerning amendments to the law No. 30 of 2004 concerning Notary. 2) To identify and analyze problems and solutions for the implementation of a legitimate presumption that a deed Partij Notary according to Law No. 2 of 2014 concerning amendments to the law No. 30 of 2004 concerning Notary. The data used in this study are primary data, secondary data and data that can support tertiary study, which was then analyzed by normative.

Based on the results of data analysis concluded that: 1) an assessment of the Deed as the product of a public official, it must be done with the presumption of unauthorized or Vermoeden van rechtmatigheid or Presumptio lustae Causa, the Deed must be considered valid until there are those who claim deed is invalid then in the contested through the courts and there is a court decision that has permanent legal force 2 ) in the implementation of the principle of presumption valid for notaries who make Partij deed still major obstacles in the face by the Notary Public. Such constraints due to actions undertaken by the giving false information to the Notary in the process is an authentic deed, causing loss to the parties who feel aggrieved. The solution of the presumption of lawful implementation for notaries who make Partij deed is the absence of legal protection and legal justice for notaries who here become victims of false information given by to the Notary. In the event of the above, none of the violations committed by the Notary. Because of the early events at the root of the problem are the bad faith of the Notary. So that the implementation of their legitimate presumption that a deed Partij Notary shall apply. Because of the early events at the root of the problem are the bad faith of the Notary. So that the implementation of their legitimate presumption that a deed Partij Notary shall apply. Because of the early events at the root of the problem are the bad faith of the Applicant. So that the implementation of their legitimate presumption that a deed Partij Notary shall apply. Keywords: Principle of Legal Presumption, Notary, Partij deed.
\end{abstract}

\section{Introduction}

In the draft Civil Code Article 1313, the Agreement is the act by which one or more persons bind himself to one or more other people. The validity of a treaty requirement stated in the Code of Civil Code Article 1320. The form of the agreement is divided into written agreements and verbal agreements. The written agreement can be shaped deed. While the form of a deed to be an authentic deed and the deed under hand.

In the Book of the Law of Civil Law Section 1868 authentic deed is "... is a deed in the form prescribed by law, made by or in the presence of public servants in power to the

\footnotetext{
${ }^{1}$ Student of Master of Notary Law, Faculty of Law, University Islam Sultan Agung Semarang email najmiamudy@gmail.com

2 Students of Master of Law, Faculty of Law, Universitas Islam Sultan Agung Semarang, Semarang email sujatmika2003@gmail.com

${ }^{3}$ Faculty of Law, Universitas Islam Sultan Agung Semarang, Semarang
} 
place where the deed was made". Terms of authentic deed by Philip M. Hadjon are: ${ }^{4}$ (1) In form prescribed by law; (2) Made by and in the presence of public officials. Public officials who are addressed one of which is a Notary Public. Notary has clear definition contained in Law No. 2 of 2014 concerning amendments to the law No. 30 of 2004 concerning Notary. Being professional is a must for notaries who run the office. It is listed in Law No. 2 of 2014 concerning Notary Article 16 letter a.

Authentic Deed itself has three strength of evidence that formal proof strength, the strength of evidence material. And the strength of evidence that proves that the binding between the parties and third parties that on the date of the deed in question has been facing the general staff and explain what it is written. ${ }^{5}$

Notarial deed is authentic deed which has the force of law to guarantee legal certainty as a perfect tool written evidence (volledig bewijs), does not require additional tools other evidence, and the judge is bound by it. ${ }^{6}$ Probative value of the notarial deed outer aspect should be seen for what. ${ }^{7}$ Parameters to determine the notarial deed as an authentic deed, the signature of a Notary is concerned, whether there is at Minuta and Copies and the beginning of the deed (from the title) until the end of the deed. ${ }^{8}$ In addition, the notary deed is special because the Deed is a product of public officials, the assessment of the Deed shall be made with a valid presumption. The purpose of the assessment is mandatory Deed is considered correct and valid until there are those who claim and can prove the authenticity and validity of the certificate is not valid with the way the party should sue to the General Court. During and throughout the claim process is running, the certificates remain valid and remain binding on the parties as well as people with an interest in such deed, to 5 Retnowulan Oeripkartawinata Sutantio and Iskandar, 1979, the Civil Procedure Code.

In the implementation of the principle of presumption valid for notaries who make Partij deed still major obstacles in the face by the Notary Public. Such constraints due to actions undertaken by the giving false information to the Notary in the process is an authentic deed, causing loss to the parties who feel aggrieved. The solution of the presumption of lawful implementation for notaries who make Partij deed is the absence of legal protection and legal justice for notaries who here become victims of false information given by to the Notary. In the event of the above, none of the violations committed by the Notary. Because of the early events at the root of the problem are the bad faith of the applicant.

Based on the background mentioned above, the authors are interested in doing further research to be manifested in a study entitled "Implementation Principles For Notary Makes Deed Partij According to Law No. 2 of 2014 on the Amendment of Act No. 30 of 2004 on Notary ".

\section{Research methods}

The method used in this research is descriptive analysis approach. Descriptive analysis

\footnotetext{
4 Philip M. Hadjon, 31 January 2001, "Land Registration Form is not an authentic deed", Surabaya Post, p. III.

${ }^{5}$ Retnowulan Sutantio and Iskandar Oeripkartawinata, 1979, Hukum Acara Perdata

Dalam Teori dan Praktik, Bandung: Mandar Maju, p. 67.

${ }^{6}$ AA Andi Prajitno 2010, Apa dan Siapa Notaris di Indonesia?, First Edition, Surabaya: Putra Media Nusantara, p.51.

7 Habib Adjie 2010, Kebatalan dan Pembatalan Akta Notaris, Surabaya: PT. Refika Aditama, p. 18-19.

${ }^{8}$ Habib Adjie 2009, Hukum Notaris Indonesia, Bandung: PT Refika Aditama, p. 26.
} 
Volume 6 Issue 4, December 2019

Nationally Accredited Journal,

Decree No. B/4130/E5/E5.2.1/2019

approach in this study, is the approach in terms of legislation and legal norms in accordance with the existing problems.

\section{Research and Discussion}

\subsection{Implementation of the principle of presumption of their legitimate Notary makes Partij deed according to Law No. 2 of 2014 concerning amendments to the law No. 30 of 2004 concerning Notary Position}

Deed is a signed letter, containing information about the events or things that are the basis of an agreement. Article 1867 of the Civil Code states Proof by writing done with the authentic writings or by writing under his hand. From the article mentioned above, the type of certificate consists of two types of deed under the hand and authentic deed.

According to Section 1868 Book of the Law of Civil Law, an authentic deed is a deed made in the form prescribed by the Act by or in the presence of a public official authorized to it in the certificate was made.

Deed has two functions: a formal function and the function of evidence. Formalities means deed serves to complete or perfect a legal act, so it is not the validity of a legal act. In this context the deed is a formal requirement for the existence of a legal act. Probation means the deed has the function as evidence, because since the beginning of the deed was created intentionally to proof later. The nature of an agreement in the form of a written deed does not make the validity of the agreement but merely to be used as evidence in the future.

As has been described above that according to the Code Article 1868 Civil Code, Notary deed certificates classified as inauthentic. There are also provisions regarding the authority of the Notary to create an authentic deed stipulated in Law No. 2 of 2014 on the Amendment of Act No. 30 of 2004 concerning Notary. In Article 1 point 1 UUJN, mentioned that a Notary is a public official, which is authorized to make an authentic deed and have more authority as referred to in this Act or under any other laws.

Fundamentally, the Civil Procedure Code recognize three kinds of letters, namely: regular mail, deed under the hand and authentic deed. Compared with ordinary letter and deed under hand, authentic certificate is sufficient proof or evidence that was perfect. Notarial deed is authentic deed which has the force of law to guarantee legal certainty as a perfect tool written evidence (volledig bewijs), does not require additional tools other evidence, and the judge is bound by it. ${ }^{9}$ This means that the content of this fact by the judge considered to be true, unless the evidence put forward a strong opponent. Which meant that the judge should believe what is written in the deed, in other words what is contained in the certificate must be true to not be proved against third parties. The notarial deed as evidence in order to have the strength of evidence was perfect, if all the provisions of the procedure or procedures for a deed fulfilled. ${ }^{10}$

In the manufacture of a notary deed there are two things that make the notarial deed is said to be lawful: first, notaries authorized to make the deed in accordance with the wishes of the parties. Second, outwardly, formal and material compliance with the law

\footnotetext{
${ }^{9}$ AA Andi Prajitno 2010, Apa dan Siapa Notaris di Indonesia?, First Edition, Surabaya: Putra Media Nusantara, p. 51.

${ }^{10} \mathrm{ibid}$, P. 126.
} 
on the notary deed. ${ }^{11}$ Notary deed as a product of public officials, the assessment of the notarial deed should be done with the presumption of legitimate (Vermoeden van rechtmatigheid) or Presumptio Iustae Causa. ${ }^{12}$ This principle can be used to assess the notarial deed, the Notary deed that must be considered valid until the parties declared the certificate invalid. ${ }^{13}$ That to declare or assess the unauthorized deed must lawsuit before a general court. During and throughout the lawsuit run until there is a court decision which has permanent legal force, then the deed of Notary remain valid and binding on the parties, or anyone with an interest in the deed. ${ }^{14}$

Presumption of lawful relates to the deed can be canceled, an act is flawed, that is not competent Notary to make deed outwardly, formal, material, and not in accordance with the rules of the law of the making of notarial deed, and this principle cannot be used to assess deed null and void, because the certificate is considered null and void was never made.

Presumption of legitimate force, with the provision that if on notarial deed was never filed a cancellation by an interested party to the general court (domestic) and there have been court rulings general who already have permanent legal force or notarial deed does not have the strength of evidence as the deed under hand or not null and void is not canceled by the parties themselves. Thus the application of the presumption of legitimate notarial deed is limited, if the conditions as mentioned above are met. Minuta deeds then it should stay in the relevant notarial deed bundle, and Notary concerned or the holder of the protocol is still authorized to issue a copy of it at the request of the parties or their heirs concerned. Giving the copy is made by notary for the notarial deed is an act of the parties, and the parties are entitled to a copy of the deed, and the Notary shall prepare and provide a copy of it. Entered into force invalidated since there is a court decision which has permanent legal force states notarial deed becomes invalid.

\subsection{Challenges and solutions for the implementation of the principle of presumption of legitimate Notary makes Partij deed according to Law No. 2 of 2014 concerning amendments to the law No. 30 of 2004 concerning Notary Position}

Early deed or deed head part containing a description of the deed of Notary on legal facts, so does the end of the deed or deed cover. As well as in parts of this guarantee Notary of the truth, including the certainty of the date, time and place of the reading executed deed and the signing of the deed at the seat of the Notary. If the information in deed not in accordance with this fact also means that the Notary has been giving false information.

Although in Law Notary does not mention any sanctions of punishment but a legal action against the violations committed by the Notary mentioned above contains elements of counterfeiting of the intention and negligence in the manufacture of a letter or certificate authentically describe its contents is false, then after sanctions administrative / office Notary professional code of ethics and civil penalties can then be withdrawn and qualified as a criminal act carried out by notaries who account for the evidence of the involvement intentionally committing a crime of counterfeiting

\footnotetext{
${ }^{11}$ Habib Adjie, 2017, Sanksi Perdata \& Administratif Terhadap Notaris Sebagai Pejabat Publik, Bandung: Refika Aditama, p. 79.

${ }^{12}$ Ibid.

${ }^{13}$ Ibid p. 80.

${ }^{14}$ Ibid p. 80.
} 
Volume 6 Issue 4, December 2019

Nationally Accredited Journal,

Decree No. B/4130/E5/E5.2.1/2019

authentic deed. The error in any form if it is proved that it is the duty to account for the Notary deed made by or before him who reaps the error.

Notary Deed contains statements, statements of the parties and made the will or request of the parties, and Notary made in a form prescribed by law, and also Notary not a party to the deed, the inclusion of the name of the Notary deed for orders legislation. Even if there are false statements or information allegedly included inserted into an authentic deed, the deed does not cause false. ${ }^{15}$

There are three possible causes of the description in the deed does not correspond to reality. The first, the omission of the Notaries in deed. Secondly, the intention of the Notary to assist in giving false testimony in deed. Third, the bad faith of the applicant to give false information to the Notary.

In the implementation of the principle of presumption valid for notaries who make Partij deed still major obstacles in the face by the Notary Public. So in the implementation of the legitimate presumption can be concluded not implemented completely. Obstacles faced by the Notary arising from actions undertaken by the giving false information to the Notary in the process is an authentic deed, causing loss to the parties who feel aggrieved.

The solution of the presumption of lawful implementation for notaries who make Partij deed is the absence of legal protection and legal justice for notaries who here become victims of false information given by to the Notary. Notary as a public official who runs the profession in providing legal services to the community needs to get protection and guarantee the interests of justice laws. Notary already implementing Articles 15, 16 and 17 of Law Notary. In the event of the above, none of the violations committed by the Notary. Because of the early events at the root of the problem are the bad faith of the applicant. So that the implementation of their legitimate presumption that a deed Partij Notary shall apply.

\section{Closing}

\subsection{Conclusion}

Based on the research results can be concluded as follows:

- Deed authentic as described in Article 165 HIR that authentic deed as evidence of the strongest and most have an important role in every relationship in public life. Notary Deed certificates classified as inauthentic if disqualify the achievement of an authentic deed. Then an assessment of the notarial deed must use a valid presumption. This principle has been recognized in Law Notary mentioned in Explanation General section confirmed that, as written evidence that the strongest and most, what is stated in the Deed must be accepted, unless the parties concerned can prove otherwise satisfactorily before the trial court.

- In the implementation of the principle of presumption valid for notaries who make Partij deed still major obstacles in the face by the Notary Public. The cause of these obstacles because the actions undertaken by the giving false information to the Notary in the process is an authentic deed, causing loss to the parties who feel aggrieved. The solution of the presumption of lawful implementation for notaries who make Partij deed is the absence of legal protection and legal justice for notaries who here become victims of false information given by to the Notary.

\footnotetext{
${ }^{15}$ Habib Adjie 2009, Hukum Notaris Indonesia, Bandung: PT Refika Aditama, p. 29.
} 


\subsection{Suggestion}

- In the case of the alleged it unlawful notarial deed, the parties concerned need to promote and apply the principle of presumption of legitimate against Partij deed. Society needs in education regarding legitimate presumption against Partij deed for the protection and legal justice for the Notary.

- Notary public officials serving the public need for protection and legal justice. Notary Honorary Council is one legal entity whose role is to create the legal protection and justice for its members. Notary Honorary Council's role is indispensable to apply the principle of legitimate for notaries who make Partij deed.

\section{References}

[1] AA Andi Prajitno 2010, Apa dan Siapa Notaris di Indonesia?, First Edition, Surabaya: Putra Media Nusantara

[2] Habib Adjie 2009, Hukum Notaris Indonesia, Bandung: PT Refika Aditama

[3] Habib Adjie 2010, Kebatalan dan Pembatalan Akta Notaris, Surabaya: PT. Refika Aditama

[4] Habib Adjie, 2017, Sanksi Perdata \& Administratif Terhadap Notaris Sebagai Pejabat Publik, Bandung: Refika Aditama

[5] Philip M. Hadjon, 31 January 2001, "Land Registration Form is not an authentic deed", Surabaya Post.

[6] Retnowulan Sutantio and Iskandar Oeripkartawinata, 1979, Hukum Acara Perdata Dalam Teori dan Praktik, Bandung: Mandar Maju

[7] Soerjono Soekanto, Pengantar Penelitian Hukum, Jakarta: University of Indonesia Press 